\title{
Performance Analysis of Three Level Diode Clamped Inverter fed Induction Machine using Multicarrier PWM Techniques
}

\author{
G. Manohar ${ }^{1}$ and Dr. S. Venkateshwarlu ${ }^{2}$ \\ ${ }^{1}$ Assoc. Professor, CVR College of Engineering/EEE Department, Hyderabad, India \\ manohar.gangikunta@gmail.com \\ ${ }^{2}$ Professor, CVR College of Engineering/EEE Department, Hyderabad, India \\ svip123@gmail.com
}

\begin{abstract}
The Utilization of multilevel inverter technology in induction machine applications is attaining highest interest in the last two to three decades. Out of the three classical multilevel inverter topologies, diode clamped multilevel inverter topology is widely used due to its high efficiency, minimized stress on power switching devices and decreased number of capacitors. This paper presents the performance analysis of three phase, three level diode clamped inverter fed induction machine in open loop operation, as well as closed loop operation with proportional integral controller using different multi carrier pulse width modulation techniques.
\end{abstract}

Index Terms: Diode Clamped Multilevel Inverter (DCMLI), Multi carrier pulse width modulation, Total harmonic distortion (THD), Phase Disposition (PD), Phase Opposition and Disposition(POD)

\section{INTRODUCTION}

Multilevel inverter fed induction machines tends to gain continuous interest in $R \& D$ and industrial sector as they have a quite number of applications in both drives and utility sectors. Initially induction motor drives were employed in constant speed applications. Due to advent of new semiconductor switching devices, power electronic converters and developments in the controllers, induction motor drives are employed in variable frequency applications also. Nearly $80 \%$ of the ac motor drives used in industries are induction motor drives only. The major advantage of inverter fed induction motor drives is its ability to synthesize the control voltage vectors for different applications. Usage of Multilevel inverter fed induction machines (induction generators) in wind power generation is gaining tremendous interest both in R\&D sector as well as power system sector [1]. Multilevel inverter fed induction machines driven by wind turbines are used in wind power generation both in squirrel cage induction generators and doubly fed induction generators [2]. These induction machines can be either operated in islanding mode or grid connected mode, depending on type of induction machine used.

Invention of vector control or Field Oriented Control (FOC) of induction motors in early 70 s by F.Blaschke, led to the tremendous development in the AC motor drives [3]. Later technologies like Sine Pulse Width modulation (SPWM) and Space Vector Pulse Width Modulation (SVPWM) were introduced to control the effective on period of the semiconductor switches [4-6]. Direct Torque Control (DTC) of induction motors was discussed in [7]. Sensor less control of induction motors using vector control is discussed in [8]. In [9], hybrid DTC of induction motor drives was discussed

Block diagram of diode clamped inverter fed induction machine is shown in Figure 1. The input to the diode clamped inverter can be either dc link capacitor or dc voltage source. Induction machine can be either operated as induction motor (as in case of motor drives) or induction generator (as in case of wind generators) depending on load torque. A PI controller is used in the feedback mechanism. However, this controller can be replaced by many of the artificial controllers like neural network controller, fuzzy logic controller or combination of fuzzy-neuro controller, depending on requirement.

This paper is organized as follows. Importance of multilevel inverters and their classification is discussed in section II. Multi carrier PWM techniques are discussed in section III. Simulation studies and results are presented in section IV and conclusions are in section V.

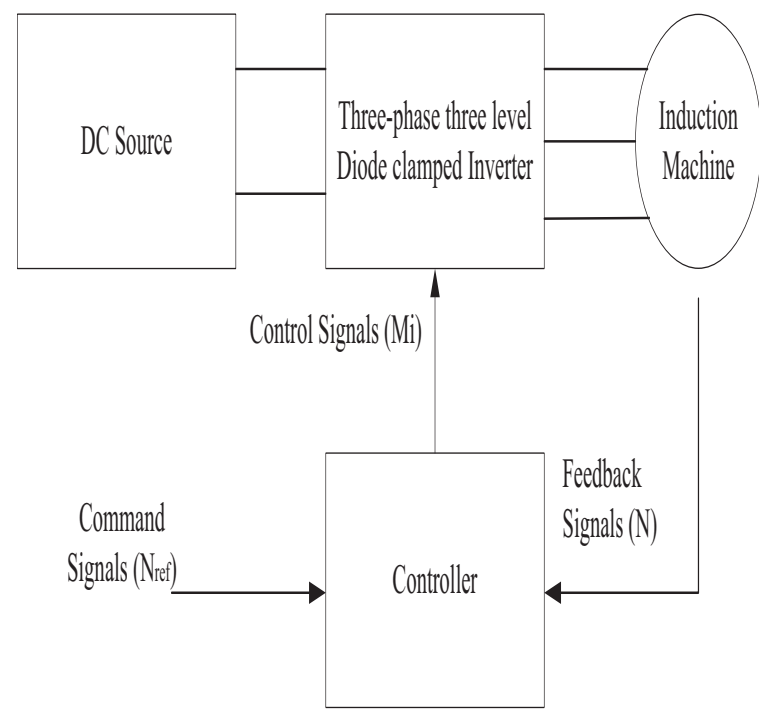

Figure 1. Block diagram of inverter fed induction machine 


\section{MultiLeVEL INVERTERS}

The major limitation of conventional two-level Voltage Source Inverter (VSI) is that it's output voltage has only two levels i.e. $+\mathrm{V}_{\mathrm{dc}}$ or $-\mathrm{V}_{\mathrm{dc}}$, where $\mathrm{V}_{\mathrm{dc}}$ is the input dc voltage of the Inverter. As a result, rate of change of output voltage $\mathrm{dv} / \mathrm{dt}$ is very high, and is about $10000 \mathrm{~V} / \mathrm{sec}$. One more major drawback is presence of harmonics in the output voltage. High winding losses will occur if the output voltage of two level VSI is fed to the induction motor. To overcome the above-mentioned limitations, multilevel inverters are generally used in place of two-level inverters.

A multilevel inverter may be defined as power electronic converter which converts fixed DC to variable ac having more than two levels in its pole voltage using low rating power semiconductor switching devices [10].

The major advantages of multilevel inverters are

- Lower common mode voltages

- Lower harmonic distortion

- Generation of higher voltages using low rating switching devices

- Can operate at low switching frequency

- Suitable for medium power, high voltage applications

Multilevel inverters can be broadly classified into three types. They are

1. Diode Clamped multilevel inverter

2. Flying capacitor multilevel inverter

3. Cascaded $\mathrm{H}$ bridge multilevel inverter

\section{A. Diode Clamped Multilevel Inverter}

It is the most commonly used and popular topology of multilevel inverter. Diodes are used as clamping devices to clamp different levels of voltages, hence named as diode clamped multilevel inverter (DCMLI). At the input side of the inverter the dc bus capacitance is split into two equal capacitances providing a neutral point ' $\mathrm{O}$ '. When the middle switches of any leg of the inverter are turned on, the respective phase is connected to the neutral point ' $O$ ' through one of the clamping diodes. As a result, the voltage is clamped to either $+0.5 \mathrm{~V}_{\mathrm{dc}}$ or $-0.5 \mathrm{~V}_{\mathrm{dc}}$ depending on direction of current through the load. When top two switches are turned on, the output voltage is $+V_{\mathrm{dc}}$ and when bottom two switches are on, the output voltage is $-V_{d c}$.

The formulae for number of active switching devices, clamping diodes and dc bus capacitors is given by $6(\mathrm{~m}-1)$, $3(\mathrm{~m}-1)(\mathrm{m}-2)$ and $(\mathrm{m}-1)$ respectively, where $\mathrm{m}$ is the level of the inverter. Thus a 3-level diode clamped inverter requires 12 active switching devices, 6 clamping diodes and 2 dc bus capacitors [11].

\section{Advantages of Diode clamped multilevel inverter}

- Maximum voltage across any switch is half the value of dc source voltage

- When leakage current of top and bottom switches is greater than leakage current of inner switches, there is no need for additional components to achieve static voltage equalization.

- As the number of levels increases, THD decreases.

- For a given fundamental frequency, efficiency is higher.

Disadvantages of Diode clamped multilevel inverter

- Uneven loss distribution in the devices (Inner switching devices are overloaded compared to the outer switching devices).

- Number of clamping diodes increases as the level increases hence the complexity of the circuit increases

- Active power flow is very difficult

- Voltage imbalance across the dc bus capacitors

- Complexity of the triggering circuit increases with increase in number of levels

The circuit diagram of a three phase, three-level diode clamped multilevel inverter is shown in the Figure 2.

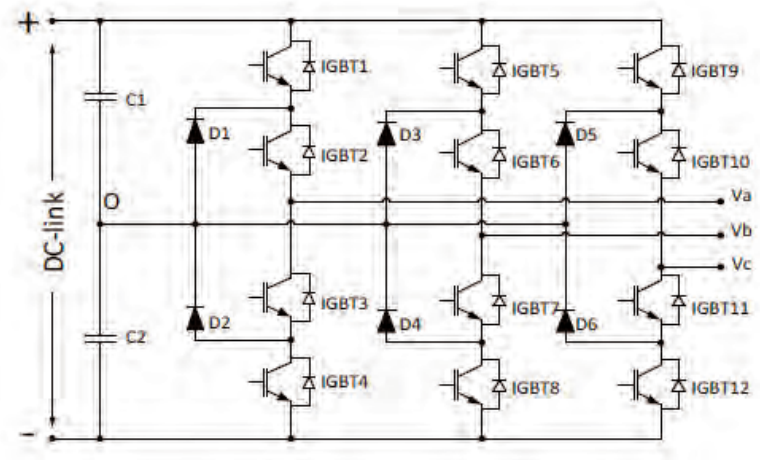

Figure 2. Three phase, three level diode clamped multilevel inverter

\section{B. Flying Capacitor Multilevel Inverter}

If the clamping diodes in DCMLI are replaced by capacitors, the resulting topology is called flying capacitor multilevel inverter (FCMLI). The flying capacitor topology is relatively newer compared to diode clamped topology. The process of synthesizing output voltage is more flexible in flying capacitor multilevel inverter compared to the diode clamped multilevel inverter.

Advantages

- No voltage imbalance problems across the dc bus capacitors

- Both active and reactive power flow control can be achieved

Disadvantages

- Requirement of large number of capacitors makes the converter bulky and expensive.

- Switch utilization and efficiency is poor, especially for real power transmission. 
A three phase, three level flying capacitor inverter is shown in figure 3 .

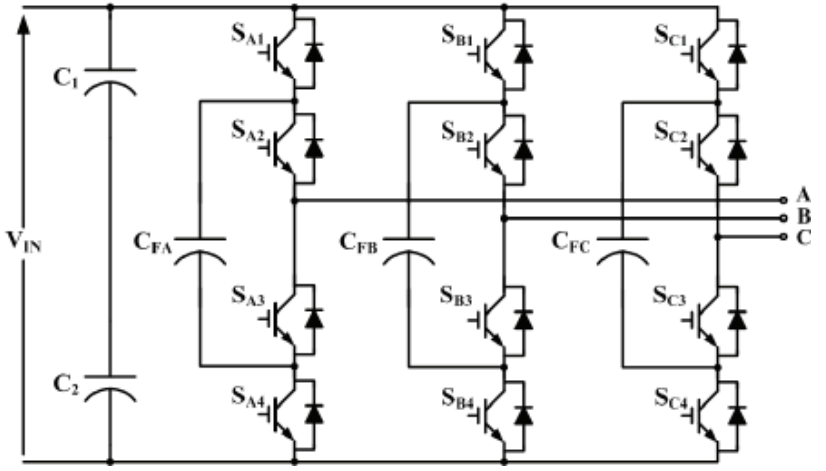

Figure 3. Three -phase, three level, flying capacitor multilevel inverter

\section{Cascaded H-Bridge Multilevel Inverter}

A cascaded $\mathrm{H}$ bridge multilevel inverter is constructed by connecting large number of single-phase $\mathrm{H}$ bridge cells in cascade at ac side. This topology requires large number of dc sources at input side unlike that of Diode clamped and Flying capacitor multilevel inverters

\section{Advantages}

- Less number of switching devices compared to DCMLI and CCMLI

- More number of levels can be synthesized when input dc sources have different magnitudes

- Doesn't require any additional capacitors or clamping diodes for voltage balancing

\section{Disadvantages}

- Needs separate dc sources

Cascaded H-Bridge multilevel inverters are now gaining high interest in the field of Distributed generation and solar photo voltaic inverters.

A single leg of a three-phase three-level cascaded, $\mathrm{H}$ bridge multilevel inverter is shown in figure 4 .

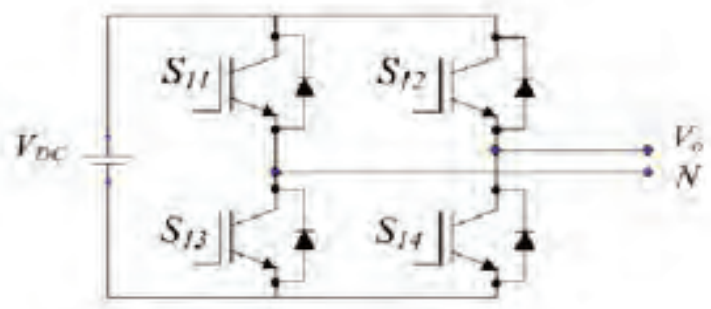

Figure 4. One leg of a three- phase cascaded $\mathrm{H}$ bridge three level Inverter

A detailed comparison table on basic multilevel inverter topologies in terms of number of power semiconductor switches, clamping diodes and DC bus capacitors is given in Table I.
TABLE I.

COMPARISON TABLE OF DIFFERENT MULTILEVEL INVERTER TOPOLOGIES

\begin{tabular}{|c|l|c|c|c|}
\hline S.No & \multicolumn{1}{|c|}{ Topology } & $\begin{array}{c}\text { Diode } \\
\text { Clamped }\end{array}$ & $\begin{array}{c}\text { Flying } \\
\text { Capacitor }\end{array}$ & $\begin{array}{c}\text { Cascaded } \\
\text { H-Bridge }\end{array}$ \\
\hline 1 & $\begin{array}{l}\text { Power Semiconductor } \\
\text { Switches }\end{array}$ & $2(\mathrm{~m}-1)$ & $2(\mathrm{~m}-1)$ & $2(\mathrm{~m}-1)$ \\
\hline 2 & $\begin{array}{l}\text { Clamping Diodes per } \\
\text { phase }\end{array}$ & $(\mathrm{m}-1)(\mathrm{m}-2)$ & 0 & 0 \\
\hline 3 & DC bus Capacitors & $(\mathrm{m}-1)$ & $(\mathrm{m}-1)$ & $(\mathrm{m}-1) / 2$ \\
\hline 4 & $\begin{array}{l}\text { Balancing Capacitors } \\
\text { per phase }\end{array}$ & 0 & $(\mathrm{~m}-1)(\mathrm{m}-2) / 2$ & 0 \\
\hline
\end{tabular}

\section{Multi Carrier PWM Techniques}

For controlling the induction motor parameters like speed etc., carrier based PWM techniques are used in control circuit of inverter. Multi carrier based PWM techniques can be broadly classified into two types. They are [12].

- Level shifted modulation

- Phase shifted modulation

Level shifted modulation is further classified into

- $\quad$ Phase Disposition (PD)

- $\quad$ Phase opposition disposition (POD)

- Alternative phase opposition disposition (APOD)

\section{A Level Shifted Modulation}

In level shifted modulation scheme, (m-1) triangular carrier wave forms are required, that have same magnitude and frequency. The frequency of the carrier wave decides the switching frequency of the inverter whereas frequency of the sinusoidal reference waveform is as that of desired output frequency of the inverter.

In phase disposition level shifted modulation method all the carrier waves are in phase with each other, where as in phase opposition and disposition, the carrier waveforms above reference are in phase, but they are in phase opposition with carrier waveforms which are below reference.

In alternative phase disposition, all carrier waveforms are in opposition disposition. For a five-level diode clamped inverter, number of carrier waveforms required are (5-1) four.

Level shifted multi carrier modulation scheme for fivelevel inverter is shown in Figure 5. The $\mathrm{x}$ axis parameter in figure 5 is time in seconds.

\section{B. Phase Shifted Modulation}

In phase shifted multi carrier modulation scheme all carrier waveforms will have same switching frequency and magnitude but these carrier waveforms are adjacent to each other displaced by a phase shift given by $\quad \theta=\left(360^{\circ}\right.$ $/ \mathrm{m}-1)$ where $\mathrm{m}$ is the level of the pole voltage of the inverter [13].

The peak to peak value of the reference sinusoidal waveform must be same as the peak to peak value of the triangular carrier waveforms. For a 3-level diode clamped 
multilevel inverter, number of carrier waveforms required are 2 and phase shift angle is $180^{\circ}$. For a five level diode clamped inverter, number of carrier waveform required are 4 and phase shift angle between carrier waveforms is $90^{\circ}$
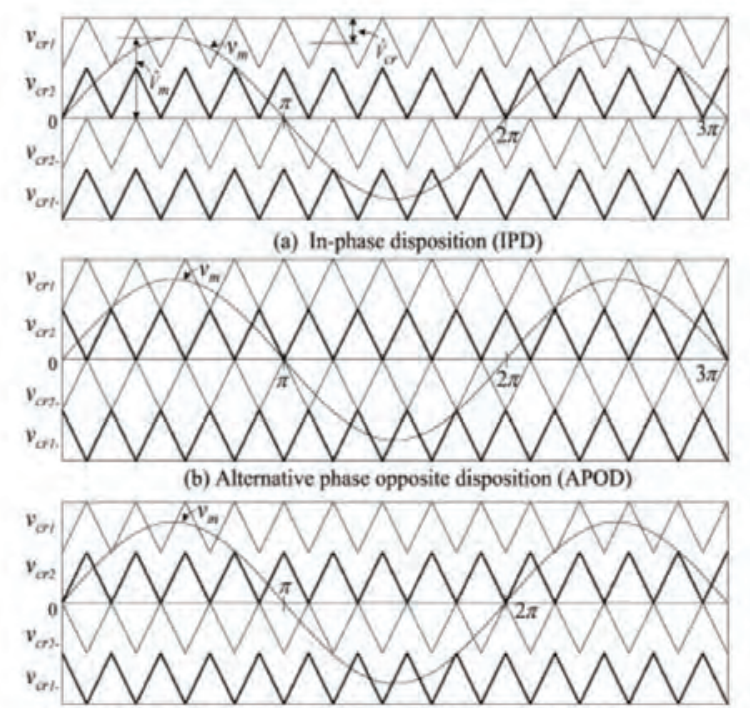

(c) Phase opposite disposition (POD)

Figure 5 Carrier waveforms for different types of level shifted Modulation

The carrier waveforms for phase shifted modulation shown in figure 6.

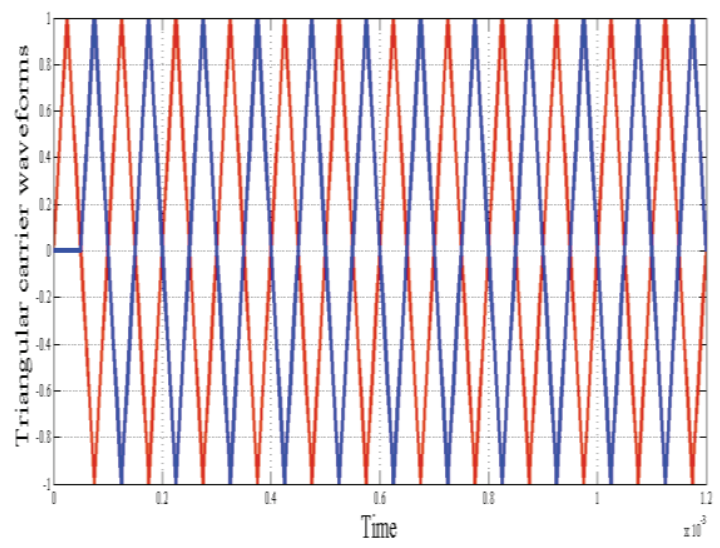

Figure 6. Carrier waveforms for phase shifted modulation

\section{Simulation StUdies ANd Results}

The three-level diode clamped inverter is fed from a constant DC source of $817 \mathrm{~V}$. Output of the inverter is given to $4 \mathrm{~kW}, 400 \mathrm{~V}, 1430 \mathrm{rpm}$ three-phase induction motor. Simulation is performed in MATLAB/SIMULINK software. The rating of the induction motor is chosen based on its suitability towards wind generation. Diode Clamped multilevel inverter is chosen for simulation since it is having high efficiency and practically used in most of the power system applications. The main objective of the paper is to track the speed of induction motor for different load changes in open loop system and in closed loop system using PI controller. PWM techniques like Phase disposition, Phase opposition and disposition and Phase shifted modulation are considered for controlling inverter, for each of these techniques Total Harmonic Distortion in the stator current of induction motor is calculated [14]. Half load torque and full load torque are applied at $1 \mathrm{sec}$ and $2 \mathrm{sec}$ respectively.

7.

The MATLAB SIMULINK diagram is shown in figure

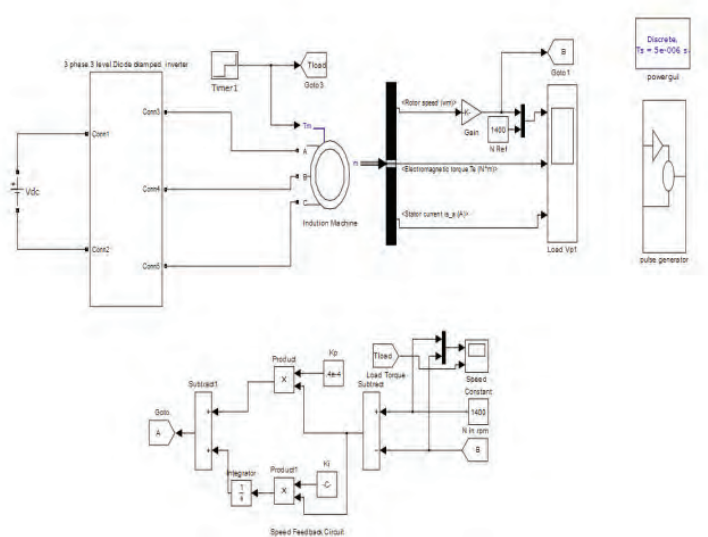

Figure 7. SIMULINK model of three level diode clamped inverter fed induction motor

Induction motor is fed by three level diode clamped inverter in open loop is simulated using SIMULINK. The frequency of the triangular carrier wave forms is $10050 \mathrm{~Hz}$ and the reference sinusoidal wave form is $50 \mathrm{~Hz}$. Amplitude modulation index is considered as 0.8 . The wave forms of speed, electromagnetic torque and stator current of induction motor in phase disposition technique are shown in figure 8.The output line voltages of the inverter are shown in figure 9.It can be clearly shown that the line voltages are having the amplitudes of $+\mathrm{Vdc} .+0.5 \mathrm{Vdc}, 0,-0.5 \mathrm{Vdc}$ and $-\mathrm{Vdc}$ and these voltages are displaced by a phase shift of $120^{\circ}$.

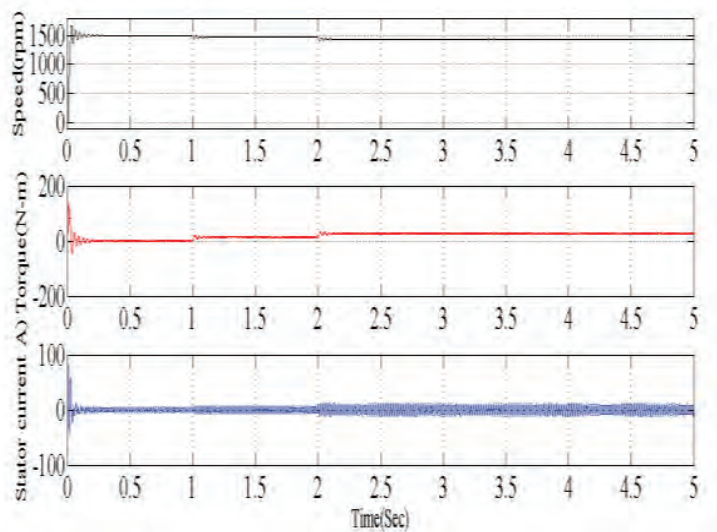

Figure 8. Speed, torque and stator current of induction motor in open loop, Phase disposition technique

At starting of the induction motor, under no load conditions, the speed reached its rated value within 0.05 seconds, At $\mathrm{t}=1$ second, when half full load torque is applied, the speed dropped to $1470 \mathrm{rpm}$. At $\mathrm{t}=2$ seconds when full load torque is applied the speed further dropped to $1435 \mathrm{rpm}$. Ripple in motor speed is less than $1 \%$ in steady 
state conditions. At starting of the induction motor the starting torque is very high at $130 \mathrm{~N}-\mathrm{m}$ which is nearly 5 times of the rated torque. The oscillations are present in the torque for 0.05 seconds and steady state is reached. The starting current under no load conditions is $80 \mathrm{~A}$, which is nearly 7 times the full load current. Steady state is reached within 0.05 seconds.

Total Harmonic Distortion (THD) of stator current for multicarrier SPWM techniques like phase disposition, phase opposition disposition and phase shifting technique is calculated for different carrier frequencies. It has been found that THD decreases with increase in switching frequency of the carrier wave. THD in stator current is very high in phase shifting carrier waveform technique at both switching frequencies. For this reason, Phase shifting carrier technique is not preferred in diode clamped inverter topologies. However, this technique is preferred in cascaded H-Bridge inverters, especially in the applications of solar photo voltaic inverters

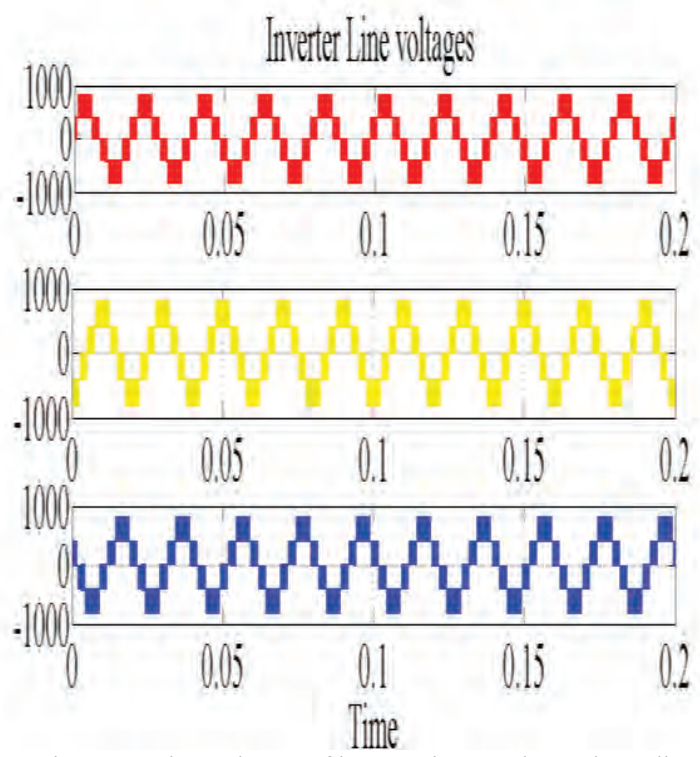

Figure 9. Line voltages of inverter in open loop Phase disposition Technique

The reference and actual speed of induction motor along with electromagnetic torque and stator current in phase ' $A$ ' for phase disposition level shifted PWM technique are shown in figure 8 . The gains of the proportional $\left(\mathrm{K}_{\mathrm{P}}\right)$ and integrator $\left(\mathrm{K}_{\mathrm{I}}\right)$ of PI controller are chosen to be 0.0004 and 0.0015 respectively so that actual speed can track the reference speed under load disturbances accurately. Here the gains $\mathrm{K}_{\mathrm{P}}$ and $\mathrm{K}_{\mathrm{I}}$ are tuned in randomly using trial and error method.

TABLE II.

THD IN STATOR CURRENT OF INDUCTION MOTOR FOR DIFFERENT TYPES OF MULTICARRIER SPWM TECHNIQUES IN OPEN LOOP SYSTEM

\begin{tabular}{|c|l|c|}
\hline S.No & \multicolumn{1}{|c|}{ Name of the SPWM technique } & $\begin{array}{c}\text { \% THD in stator } \\
\text { phase current of } \\
\text { induction motor }\end{array}$ \\
\hline 1 & $\begin{array}{l}\text { Level Shifted Phase Disposition } \\
\text { Method (PD) }\end{array}$ & 3.29 \\
\hline 2 & $\begin{array}{l}\text { Level Shifted Phase Opposition } \\
\text { Disposition Method (POD) }\end{array}$ & 3.87 \\
\hline 3 & Phase Shifted Modulation technique & 20.24 \\
\hline
\end{tabular}

TABLE III.

THD IN STATOR CURRENT OF INDUCTION MOTOR FOR DIFFERENT TYPES OF MULTICARRIER SPWM TECHNIQUES IN CLOSED LOOP SYSTEM

\begin{tabular}{|c|l|c|}
\hline S.No & \multicolumn{1}{|c|}{ Name of the SPWM technique } & $\begin{array}{c}\text { \% THD in stator } \\
\text { phase current of } \\
\text { induction motor }\end{array}$ \\
\hline 1 & $\begin{array}{l}\text { Level Shifted Phase Disposition } \\
\text { Method (PD) }\end{array}$ & 3.81 \\
\hline 2 & $\begin{array}{l}\text { Level Shifted Phase Opposition } \\
\text { Disposition Method (POD) }\end{array}$ & 4.02 \\
\hline 3 & Phase Shifted Modulation technique & 9.36 \\
\hline
\end{tabular}

To track the speed, closed loop PI controller method is adopted. The reference and actual speed of induction motor along with electromagnetic torque and stator current in phase ' $A$ ' for phase disposition level shifted PWM technique are shown in figure 10. The switching frequency of the triangular carrier wave is taken as $10050 \mathrm{~Hz}$ with a modulation index of 0.8
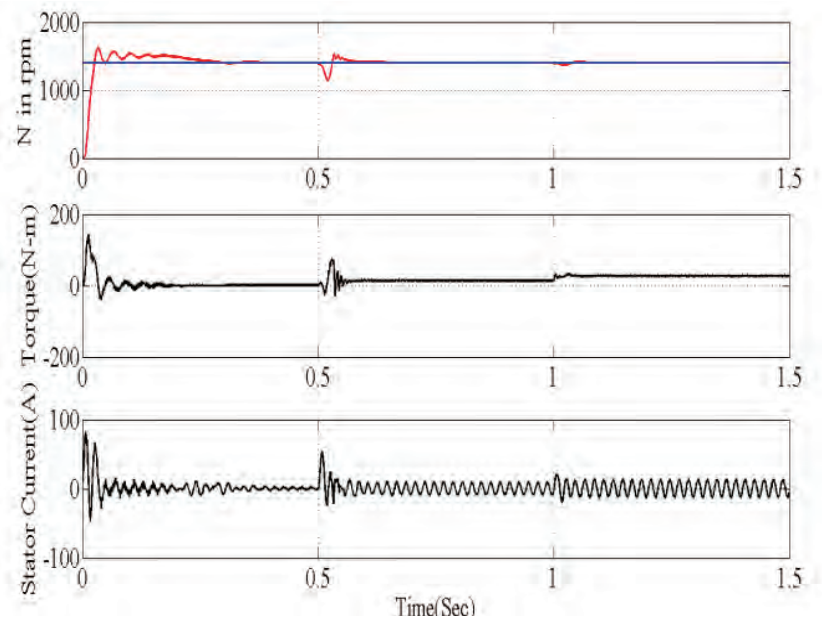

Figure10. Speed, torque and stator current waveforms of induction motor for Phase disposition technique in closed loop

Total harmonic distortion for stator current of the threephase induction motor is calculated using phase disposition level shifted PWM technique and its harmonic spectrum is shown in figure 11.

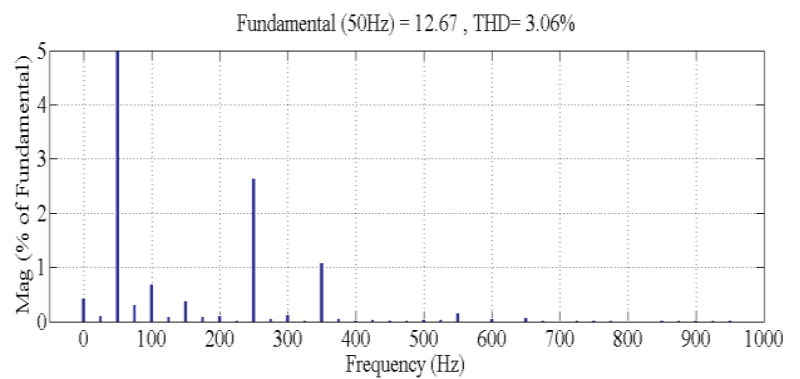

Figure11. Harmonic spectrum of stator current with PD technique

Harmonic spectrum of stator current of the three-phase induction motor for phase opposition disposition (POD) 
level shifted PWM technique and phase shifted PWM technique are shown in figure 12 and figure 13 respectively

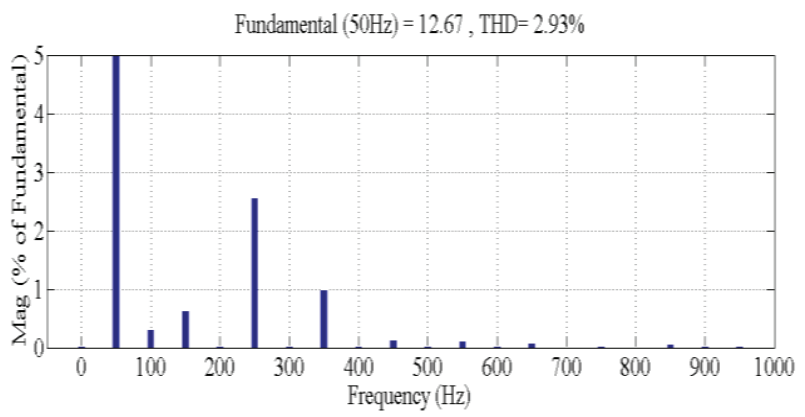

Figure 12. Harmonic spectrum of stator current with POD technique

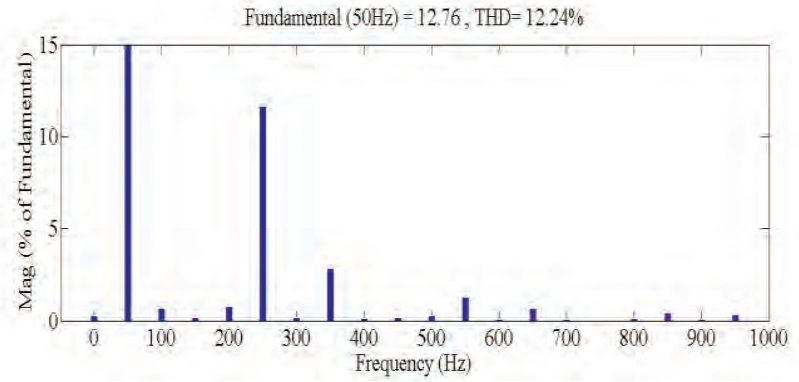

Figure 13. Harmonic spectrum of stator current with Phase shifting PWM technique

Gate pulses for the switching devices of leg1 of 3-level diode clamped inverter are shown in Figure 14.

Total Harmonic Distortion in stator current of induction motor is calculated using FFT analysis for different sinusoidal pulse width modulation (SPWM) techniques such as Phase disposition (PD), phase opposition disposition (POD) and Phase shifted modulation for switching frequency of $10050 \mathrm{~Hz}$ and $2450 \mathrm{~Hz}$ are listed in the Table II and Table III. respectively. It has been found that level shifted phase disposition method is giving less THD compared to the other methods like level shifted phase opposition disposition and phase shifted modulation. In Fast Fourier Transform (FFT) analysis, the stator current is considered under steady state conditions and FFT analysis performed at $2.7 \mathrm{sec}$ and for a single cycle.
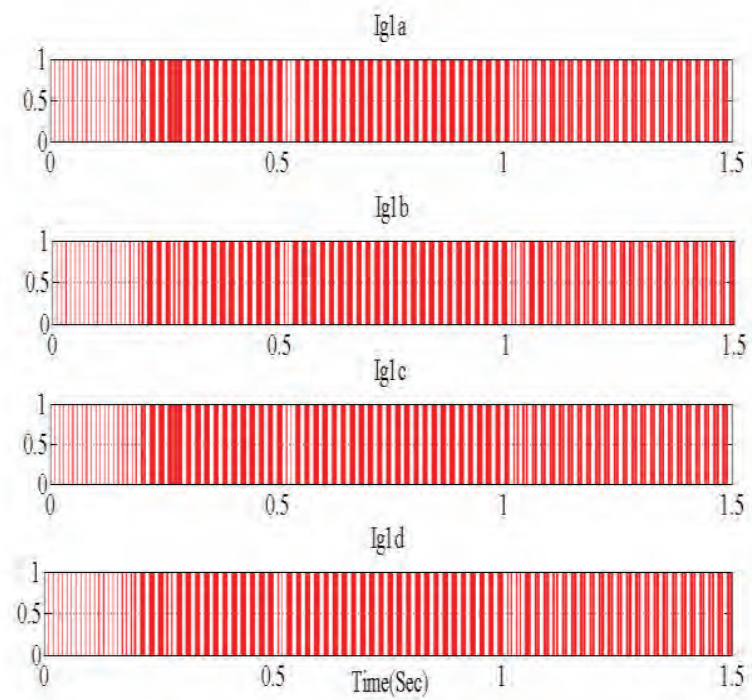

Figure 14. Gate pulses for devices of single leg of three-level diode clamped inverter
Since iUdis are naving low conducion and swicining losses, they are used as active switches in the three phase three level diode clamped multilevel inverter. Energy loss calculation for leg1 of three phase, three level diode clamped inverter in PD, POD and Phase shifted multicarrier SPWM techniques is carried out in SIMULINK and the losses of the switches are tabulated in Table IV, Table $\mathrm{V}$ and Table VI respectively. The results show that the top and bottom switches are loaded less compared to the middle switches in all the multi carrier SPWM techniques.

TABLE IV.

ENERGY LOSSES IN SWITCHES OF LEG1 OF THREE-PHASE, THREE- LEVEL DIODE CLAMPED INVERTER IN PD MULTI CARRIER SPWM TECHNIQUE

\begin{tabular}{|c|c|c|}
\hline S.No & Name of the switch & Energy loss in $\mathrm{mW}$ \\
\hline 1 & Qa1 & 71 \\
\hline 2 & Qa2 & 131 \\
\hline 3 & Qa3 & 83.7 \\
\hline 4 & Qa4 & 48 \\
\hline
\end{tabular}

TABLE V.

ENERGY LOSSES IN SWITCHES OF LEG1 OF THREE- PHASE, THREE- LEVEL DCMLI IN POD MULTI CARRIER SPWM TECHNIQUE

\begin{tabular}{|c|c|c|}
\hline S.No & Name of the switch & Energy loss in $\mathrm{mW}$ \\
\hline 1 & Qa1 & 71.8 \\
\hline 2 & Qa2 & 131.1 \\
\hline 3 & Qa3 & 84 \\
\hline 4 & Qa4 & 48 \\
\hline
\end{tabular}

TABLE VI.

ENERGY LOSSES IN SWITCHES OF LEG1 OF THREE- PHASE,THREE-LEVEL DCMLI IN PHASE SHIFTING MULTI CARRIER TECHNIQUE

\begin{tabular}{|c|c|c|}
\hline S.No & Name of the switch & Energy loss in $\mathrm{mW}$ \\
\hline 1 & Qa1 & 181.9 \\
\hline 2 & Qa2 & 232.2 \\
\hline 3 & Qa3 & 225.5 \\
\hline 4 & Qa4 & 177.4 \\
\hline
\end{tabular}

\section{CONCLUSIONS}

The performance analysis of three-phase, three- level diode clamped inverter fed induction machine is presented for various SPWM techniques. The simulation is performed in MATLAB/SIMULINK software. Speed response for various load conditions like half load and full load torque conditions is analyzed and found that the system is reaching its desired speed with in short duration of time with small 
overshoots. Total Harmonic Distortion (THD) in stator current of the induction motor is calculated for various multi carrier SPWM techniques and found that Phase disposition multi carrier SPWM technique gives much superior performance compared to the remaining SPWM techniques. Energy losses in the switches of 3 phase, 3 level diode clamped inverter are calculated and found that innermost switches are overloaded compared to the top and bottom switches.

\section{REFERENCES}

[1] Subsingha Wanchai "Design and analysis of three phase three level diode clamoed grid connected inverter" Energy Procedia, vol. 89, pp. 130-136, June 2016.

[2] Tourou, Pavlos, Michael Schael, and Constantinos Sourkounis. "Performance analysis of doubly fed induction generators operating in weak power systems." In Electrotechnical Conference (MELECON), 2016 18th Mediterranean, pp. 1-5. IEEE, 2016

[3] F.Blaschke, "The Principle of Field Orientation as Applied to the new Closed Loop Control System for Rotating Field Machine", Siemens Rev.,Vol,37,No5,pp.217-220,June 1972

[4] Boost, Michael A., and Phoivos D. Ziogas. "State-of-the-art carrier PWM techniques: A critical evaluation." IEEE transactions on industry applications 24,Vol.2, 1988,pp.271280.

[5] Yu, Zhenyu, Arefeen Mohammed, and Issa Panahi. "A review of three PWM techniques." In Proceedings of the 1997 American Control Conference (Cat. No. 97CH36041), vol. 1, pp. 257-261. IEEE, 1997.

[6] Trzynadlowski, Andrzej M., R. Lynn Kirlin, and Stanislaw F. Legowski. "Space vector PWM technique with minimum switching losses and a variable pulse rate [for VSI]." IEEE Transactions on Industrial Electronics 44, no. 2 (1997): 173181.

[7] Habetler, Thomas G., Francesco Profumo, Michele Pastorelli, and Leon M. Tolbert. "Direct torque control of induction machines using space vector modulation." IEEE Transactions on industry applications 28, no. 5 (1992): 1045-1053.

[8] Vas, Peter. Sensorless vector and direct torque control. Oxford Univ. Press, 1998.

[9] Patil, UdayKumar V., Hiralal Murlidhar Suryawanshi, and Mohan M. Renge. "Closed-loop hybrid direct torque control for medium voltage induction motor drive for performance improvement." IET Power Electronics 7, no. 1 (2014): 31-40.

[10] Rodriguez, Jose, Jih-Sheng Lai, and Fang Zheng Peng. "Multilevel inverters: a survey of topologies, controls, and applications." IEEE Transactions on industrial electronics 49, no. 4 (2002): 724-738.

[11] Marchesoni, Mario, and Pierluigi Tenca. "Diode-clamped multilevel converters: a practicable way to balance DC-link voltages." IEEE Transactions on Industrial Electronics 49, no. 4 (2002): 752-765.

[12] McGrath, Brendan Peter, and Donald Grahame Holmes. "Multicarrier PWM strategies for multilevel inverters." IEEE Transactions on industrial electronics 49, no. 4 (2002): 858867.

[13] Holmes, D. Grahame, and Thomas A. Lipo. Pulse width modulation for power converters: principles and practice. Vol. 18. John Wiley \& Sons, 2003.

[14] Messner, William C., Dawn M. Tilbury, and Asst Prof Rick Hill. "Control Tutorials for MATLAB ${ }^{\circledR}$ and Simulink ${ }^{\circledR}$." (1999). 